\title{
The perspectives of banking and health sector administrators regarding the Six Sigma ap- proach
}

\author{
Serkan Deniz ${ }^{a^{*}}$, Ünal Efe ${ }^{b}$, Mesut Cimen ${ }^{c}$ and Zeliha Tekin ${ }^{d}$
}

${ }^{a}$ Yalova University, Termal Vocational School, Yalova, Turkey

${ }^{b}$ Kuveyt Turk Participation Bank Inc., Turkey

${ }^{c}$ Aclbadem University, Faculty of Health Sciences, Department of Healthcare Management, Istanbul, Turkey

${ }^{d}$ Mus Alparslan University Vocational School of Social Sciences, Muş, Turkey

\section{H R O N I C L E}

Article history:

Received: October 1, 2016

Received in revised format: No-

vember 16, 2016

Accepted: February 12, 2017

Available online:

February 15, 2017

Keywords:

Six Sigma

Healthcare organizations

Banking

\section{A B S T R A C T}

Six Sigma is a statistics-based approach focusing on minimizing defects and variations in products and processes. Although it is used generally in production-based businesses, Six Sigma has been used in service sector businesses in the recent years as well. The aim of this study is to determine healthcare and banking sector managers' perceptions related to Six Sigma, and compare healthcare managers and banking managers in terms of their opinions about six sigma. The study was done between February 2016 and October 2016 in private healthcare organizations and private banks operating in Turkey. The intended population of the study involves the managers working in these organizations. To compare perceptions of healthcare sector managers and banking sector managers, Mann Whitney-U test was used. According to the statistical tests performed, there is not any statistically significant difference between healthcare sector managers and banking sector managers in terms of their view about Six Sigma. However, managers from the both sectors noted that Six Sigma could provide important advantages to their organizations. This result was considered as important because it indicates that Six Sigma can offer benefits for different and distinct parts of service sector, such as banking and healthcare.

\section{Introduction}

Six Sigma is a statistics-based approach focusing on minimizing defects and variations in products and processes (Desai et al., 2012, p.427). Statistically, Six Sigma refers to 3.4 defects per million opportunities (DPMO) (Antony \& Banuelas, 2002, p.21). In other words, Six Sigma aims to reach zero defect through minimizing variations in the processes, however it tolerates 3.4 defects per million (Fursule et al., 2012, p.1). Process efficiency in Six Sigma level is 99.99966 percent (Linderman et al., 2003, p.194). Six Sigma approach was developed by Motorola Company in 1987 (Heuvel et al., 2004, p.420).

* Corresponding author.

E-mail address: serkand100@gmail.com (S. Deniz) 
In Motorola, Six Sigma approach was developed in order to reach organizational goals and to improve process quality, and Six Sigma became highly successful in Motorola (Montgomery \& Woodall, 2008, p.331).

Six Sigma achieves permanent improvements in operational processes, and its advantages for companies are undeniable. In addition, Six Sigma has become a very popular management approach and adopted by organizations all over the world in order to increase efficiency, market share, profit, production and service quality through decreasing production costs, defects, and waste (Sharma \& Chetiya, 2012, p.294; Ahadian \& Abadi, 2012, p.37). Some of the important firms using Six Sigma are General Electrics, Texas Instruments, 3M, Citibank, Xerox, The Dow Chemicals, and Boeing Aircraft (Bandyopadhyay \& Coppens, 2005, p.V3). Sigma level of the process in Six Sigma is determined by defects per million opportunities (DPMO). Sigma level gives information about the defects occurring in the process. As sigma level increases, the amount of defect decreases (Türkan et al., 2009, p.107). For instance, the number of defect per million in 4 sigma level is 6210, whereas it is 233 in 5 sigma level. On the other hand, in 6 sigma level, defect per million is 3.4 (Linderman et al., 2003, p.194).

In Six Sigma, there are two important methodologies: (1) define, measure, analyze, improve, control (DMAIC), and (2) design for Six Sigma (DFSS) (Aboelmaged, 2011, p.519-520). DMAIC methodology focuses on process improvement, and, as indicated above, each letter refers to a certain stage in the process. In define (D) stage, problem is identified and cost-benefit analysis is performed. In measure (M) stage, data related to the problems are collected and the current situation is evaluated. In analyze (A) stage, factors influencing critical to quality (CTQ) characteristics are determined and the reasons behind defects are identified. In improve (I) stage, modifications and improvements required to improve performance of critical quality characteristics are performed. In control (C) stage, monitoring the improvements to ensure continued and sustainable success is performed (De Mast \& Bisgaard, 2007, p.26). Design for Six Sigma (DFSS) methodology is used for new processes or when the existing processes are insufficient to achieve organizational goals (Aboelmaged, 2011, p.520). DFSS is a proactive methodology that involves customers' feedback during the design of new products and processes (Wang et al., 2016, p.522).

Individuals participating in Six Sigma implementation have different roles and responsibilities, depending on their training and experience. These different roles and responsibilities are represented in champions, master-black belt, black belt, and green belt. Specifically, champions take responsibility for disseminating Six Sigma within the organization, and master-black belts generally serve give consultancy to project leaders. Black belts and green belts, on the other hand, implement and execute Six Sigma projects (Bandyopadhyay \& Coppens, 2005, p.V2). Even though Six Sigma is mostly used in production industry, it has been started to be used widely in the service sector as well. Numerous finance organizations and healthcare organizations all around the world have been using Six Sigma as an important part of their business strategy, and its popularity has been increasing among these organizations (Antony, 2012, p. 691). The aim of this study is to determine healthcare and banking sector managers' perceptions related to Six Sigma, and compare healthcare managers and banking managers in terms of their opinions about Six Sigma.

\section{Material and Methods}

This study was accomplished between February 2016 and October 2016 in private healthcare organizations and banks operating in Turkey. The intended population of the study involves the managers working in these organizations. Data were collected through using surveys, and 242 surveys in total were collected, however 26 questionnaire forms, in which the participants responded to the question of "Do you know Six Sigma approach?" as "No", were eliminated. As a result, 216 valid surveys were used in analyses. 
Questionnaire used in the study has two parts. In the first part, demographic characteristics of the participants are asked, and in the second part, managers' perceptions about Six Sigma approach are asked. In the development of the statements in the second part, studies done by Altuğ \& Nalbant (2013, p.313), Bircan \& Köse (2012, p.124-125), and Gosnik \& Vujica-Herzog (2010, p. 213) were used. The second part involves eight statements with 5 point Likert scale $(1=$ Totally Disagree, $2=$ Disagree, $3=$ Neither agree nor disagree, 4=Agree, 5=Totally Agree). Descriptive statistics such as frequency, percentage distribution, mean, and standard deviation were calculated. In order to determine the construct validity of the second part of the survey, in which managers' perceptions about Six Sigma were measured, Exploratory Factor Analysis (EFA) and Confirmatory Factor Analysis (CFA) were performed. In addition, fit indices were calculated, and in order to determine the reliability of the scale, Cronbach Alpha coefficient was measured. To compare healthcare managers to banking managers, in terms of their perceptions about Six Sigma, Mann Whitney-U test was used because it was seen that data do not normally distributed according to Kolmogorov-Smirnov test $(\mathrm{p}<0.05)$. Confidence interval was determined as 95 percent, and significance level was determined as 5 percent.

\section{Results}

71 of the participants are women (32.9 percent), and 145 are men (67.1 percent). The age distribution of the participants are as follows: 48 participants are between $25-30$ years (22.2 percent), 66 participants are between $31-35$ years (30.6 percent), 55 participants are between $36-40$ years ( 25.5 percent), and 47 participants are older than 40 years $(21.8$ percent). When the Education levels of the participants are examined, 48 of them have high school or two-year degree (22.2 percent), 93 have undergraduate degree (43.1 percent), and 75 of the participants have graduate degree ( 34.7 percent). 95 of the participants are junior-level managers (44 percent), 97 of the participants are medium-level managers (44.9 percent), and 24 of them are senior-level managers (11.1 percent). 110 of the participants (50.9 percent) are from banking industry, and 106 of the participants (49.1 percent) are from healthcare sector. When the tenures of the participants are examined, 45 of the participants (20.8 percent) have experience between 1-3 years, 51 of them (23.6 percent) have 4-6 years of experience, 49 of them ( 22.7 percent) have 7-9 years of experience, 30 of the participants (13.9 percent) have 10-12 years of experience, and 41 of the participants have 13 or more years of experience.

\section{Table 1}

\section{Explanatory Factor Analysis Result of Six Sigma Perceptions}

\begin{tabular}{lc}
\hline Items & Factor Loading \\
\hline SSI2. I think Six Sigma approach increases our profitability & 0.84 \\
SSI4. I think Six Sigma approach increases our service capacity & 0.84 \\
SSI5. I think Six Sigma increases patient / customer satisfaction. & 0.83 \\
SSI6. I think Six Sigma approach increases our service quality & 0.81 \\
SSI1. I think Six Sigma approach provides competitive advantage to our organization & 0.79 \\
SSI7. I think Six Sigma approach decreases the waste in our organization & 0.77 \\
SSI3. I think Six Sigma approach increases our efficiency & 0.76 \\
SSI8. I think Six Sigma approach decreases variations in the process & 0.63 \\
\hline
\end{tabular}

*SSI: Six Sigma Items

In order to determine the appropriateness of the scale to factor analysis, KMO and Bartlett tests were performed. KMO value was found to be 0.93 , and Bartlett sphericity test was found to be statistically significant $(\mathrm{p}<0.01)$. According to these results, data used in the study are appropriate for factor analysis, and there is a high correlation among the variables. The results of the Explanatory Factor Analysis are given in Table 1. Statements in the factor analysis were grouped under a single factor, which involves eight statements, and it explains 61.95 percent of the total variance. 


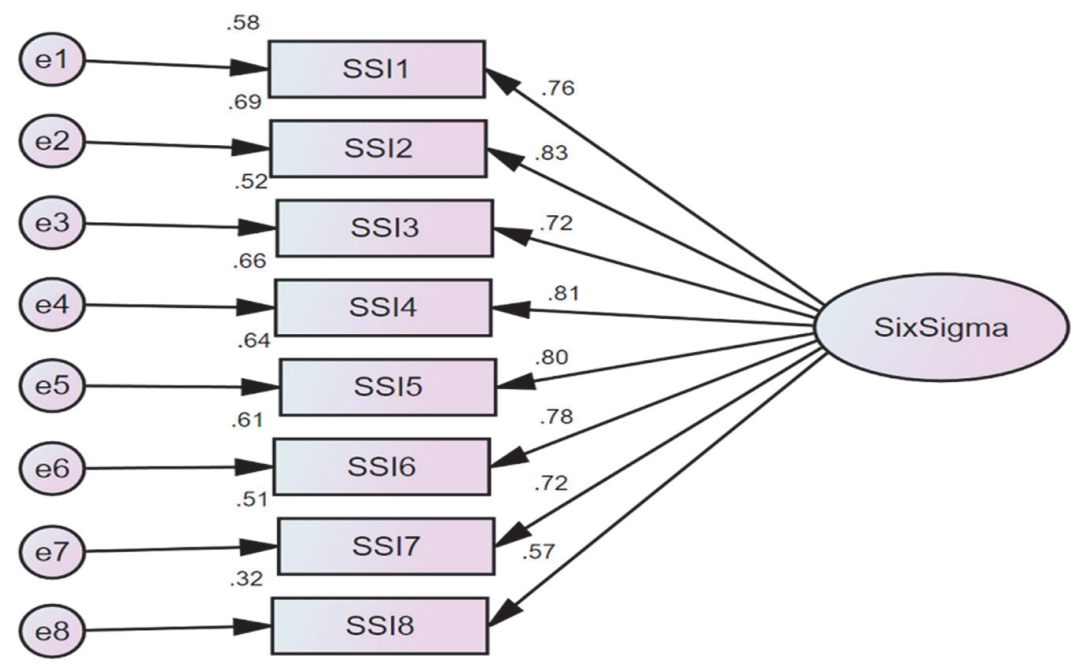

Fig. 1. Confirmatory Factor Analysis of Perceptions About Six Sigma

In order to test whether the single factor-eight statements structure of the scale is confirmed or not, Confirmatory Factor Analysis was performed. The model obtained is given in Figure 1. According to the Figure 1, it is determined that the scale is composed of eight statements. The fit indices are found to be as $\mathrm{CMIN} / \mathrm{df}=1.98, \mathrm{GFI}=0.96, \mathrm{AGFI}=0.92, \mathrm{NFI}=0.96, \mathrm{IFI}=0.98, \mathrm{TLI}=0.97, \mathrm{CFI}=0.98$, RMSEA $=0.07$. In addition, Cronbach Alpha coefficient was found to be as 0.91 . Thus, it was concluded that the scale has higher internal consistency and reliability.

Table 2

Comparison of Healthcare Managers and Banking Managers in terms of their Six Sigma Perceptions

\begin{tabular}{|c|c|c|c|c|c|c|c|c|c|}
\hline Items & Sector & $\mathbf{n}$ & Mean & $\begin{array}{l}\text { Std. } \\
\text { Deviation }\end{array}$ & $\begin{array}{l}\text { Mean } \\
\text { Rank }\end{array}$ & $\begin{array}{l}\text { Mann- } \\
\text { Whitney } \\
\text { U }\end{array}$ & $\begin{array}{l}\text { Wilcoxon } \\
\text { W }\end{array}$ & $\mathbf{Z}$ & $\begin{array}{l}\text { Sig. } \\
\text { (2-tailed) }\end{array}$ \\
\hline \multirow{3}{*}{$\begin{array}{l}\text { SSI1. I think Six Sigma approach } \\
\text { provides competitive advantage to } \\
\text { our organization }\end{array}$} & Banking & 110 & 3.96 & 0.66 & 105.85 & \multirow{3}{*}{5538} & \multirow{3}{*}{11643} & \multirow{3}{*}{-0.72} & \multirow{3}{*}{0.47} \\
\hline & Healthcare & 106 & 3.98 & 0.94 & 111.25 & & & & \\
\hline & Total & 216 & 3.97 & 0.81 & & & & & \\
\hline \multirow{3}{*}{$\begin{array}{l}\text { SSI2. I think Six Sigma approach } \\
\text { increases our profitability }\end{array}$} & Banking & 110 & 3.95 & 0.71 & 109.87 & \multirow{3}{*}{5679} & \multirow{3}{*}{11350} & \multirow{3}{*}{-0.36} & \multirow{3}{*}{0.72} \\
\hline & Healthcare & 106 & 3.89 & 0.91 & 107.08 & & & & \\
\hline & Total & 216 & 3.92 & 0.81 & & & & & \\
\hline \multirow{3}{*}{$\begin{array}{l}\text { SSI3. I think Six Sigma approach } \\
\text { increases our efficiency }\end{array}$} & Banking & 110 & 4.08 & 0.73 & 110.15 & \multirow{3}{*}{5648} & \multirow{3}{*}{11319} & \multirow{3}{*}{-0.44} & \multirow{3}{*}{0.66} \\
\hline & Healthcare & 106 & 4.03 & 0.83 & 106.78 & & & & \\
\hline & Total & 216 & 4.06 & 0.78 & & & & & \\
\hline \multirow{3}{*}{$\begin{array}{l}\text { SSI4. I think Six Sigma approach } \\
\text { increases our service capacity }\end{array}$} & Banking & 110 & 3.93 & 0.83 & 110.74 & \multirow{3}{*}{5584} & \multirow{3}{*}{11255} & \multirow{3}{*}{-0.58} & \multirow{3}{*}{0.56} \\
\hline & Healthcare & 106 & 3.89 & 0.85 & 106.18 & & & & \\
\hline & Total & 216 & 3.91 & 0.84 & & & & & \\
\hline \multirow{3}{*}{$\begin{array}{l}\text { SSI5. I think Six Sigma increases } \\
\text { patient / customer satisfaction. }\end{array}$} & Banking & 110 & 4.07 & 0.79 & 107.38 & \multirow{3}{*}{5707} & \multirow{3}{*}{11812} & \multirow{3}{*}{-0.29} & \multirow{3}{*}{0.77} \\
\hline & Healthcare & 106 & 4.08 & 0.89 & 109.66 & & & & \\
\hline & Total & 216 & 4.07 & 0.84 & & & & & \\
\hline \multirow{3}{*}{$\begin{array}{l}\text { SSI6. I think Six Sigma approach } \\
\text { increases our service quality }\end{array}$} & Banking & 110 & 4.04 & 0.81 & 109.01 & \multirow{3}{*}{5773.5} & \multirow{3}{*}{11444.5} & \multirow{3}{*}{-0.13} & \multirow{3}{*}{0.89} \\
\hline & Healthcare & 106 & 4.02 & 0.88 & 107.97 & & & & \\
\hline & Total & 216 & 4.03 & 0.85 & & & & & \\
\hline \multirow{3}{*}{$\begin{array}{l}\text { SSI7. I think Six Sigma approach } \\
\text { decreases the waste in our organi- } \\
\text { zation }\end{array}$} & Banking & 110 & 3.98 & 0.78 & 108.24 & \multirow{3}{*}{5801} & & & \\
\hline & Healthcare & 106 & 3.99 & 0.87 & 108.77 & & 11906 & -0.07 & 0.95 \\
\hline & Total & 216 & 3.99 & 0.82 & & & & & \\
\hline & Banking & 110 & 3.80 & 0.82 & 102.25 & & & & \\
\hline SSIr. I thinK Six Sigma approach & Healthcare & 106 & 3.99 & 0.85 & 114.98 & 5143 & 11248 & -1.59 & 0.11 \\
\hline & Total & 216 & 3.89 & 0.84 & & & & & \\
\hline
\end{tabular}

In Table 2, comparison of Six Sigma perceptions of healthcare managers and banking managers is given. When the perceptions of the two groups are compared, there is not a statistically significant relationship between healthcare managers and banking managers in terms of their Six Sigma perceptions $(\mathrm{p}>0.05)$. 


\section{Discussion and Conclusion}

According to the findings, there is not statistically significant difference between healthcare managers and banking managers in terms of their perceptions about Six Sigma. Participants from the both sectors noted that Six Sigma might provide important advantages to their organizations. This result is found to be important because it suggests that Six Sigma approach has important contributions to the different areas of service sector, such as healthcare and banking. Indeed, numerous other studies also support this claim as well. For instance, Kundi (2005, p.9), in his study done with production and service organizations, found that Six Sigma offers important advantages to the organizations, such as decreasing costs, defects, waste, cycle time, and increasing customer satisfaction and employee efficiency. Gosnik and Vujica-Herzog (2010, p.213), in their study with production organizations, found that Six Sigma decreases process variation, cost of poor quality, and operational costs, whereas it increases profits and efficiency. Bircan and Köse (2012, p.124), in their study with manufacturing organizations, found that participants evaluated Six Sigma as an important methodology, which provides competitive advantage by increasing production efficiency According to the study done in service sector by Antony and colleagues (2007, p.302), Six Sigma provides important contributions such as increasing market share and customer satisfaction, and decreasing defects, variations in processes, operational costs, and cycle time. Furthermore, Gowen Iii, Stock \& McFadden (2008, p.6784-6790), in their study done with hospitals, found that Six Sigma has a positive effect on sustainable competitive advantage.

According to the finding of both this study and the other studies noted above, Six Sigma approach not only has important advantages for manufacturing organizations, but also has important advantages for service organizations. In service sector, in which production and consumption of the service is simultaneous, customer satisfaction perception develops very quickly. Therefore, Six Sigma approach can be benefited more in order to improve every stage of service process. Hence, increasing customer satisfaction can be achieved. At this point, it is important to note that managers' positive perception toward Six Sigma is important. Lastly, this study focuses on service sector, whereas the future studies might focus on comparing service sector to manufacturing sector through involving bigger sample sizes. It is assumed that this kind of a comparison might yield important findings.

\section{References}

Ahadian, B., \& Abadi, A. G. M. (2012). Six Sigma pilot project selections using an MCDM approach. Management Science and Engineering, 6(1), 34-43.

Altuğ, M. \& Nalbant, M. (2011). Gains of Six Sigma projects devoted to competitiveness: Analysis of It's implementations in the manufacturing industry. Journal of Engineering and Natural Sciences, Sigma 29, 301-315.

Antony, J. (2012). A SWOT analysis on Six Sigma: some perspectives from leading academics and practitioners. International Journal of Productivity and Performance Management, 61(6), 691-698.

Antony, J., Jiju Antony, F., Kumar, M., \& Rae Cho, B. (2007). Six sigma in service organisations: Benefits, challenges and difficulties, common myths, empirical observations and success factors. International journal of quality \& reliability management, 24(3), 294-311.

Antony, J., \& Banuelas, R. (2002). Key ingredients for the effective implementation of Six Sigma program. Measuring business excellence, 6(4), 20-27.

Bandyopadhyay, J.K. \& Coppens, K. (2005). Six Sigma approach to healthcare quality and productivity management. International Journal of Quality \& Productivity Management, 5(1), 1-12.

Bircan, H. \& Köse, S. (2012). Six Sigma and companies' attitude towards Six Sigma: A study in Kayseri-Sivas Region. The International Journal of Economic and Social Research, 8(2), 107-130

De Mast, J. \& Bisgaard, S. (2007). The Science in Six Sigma. Quality Progress, 40(1), 25-29.

Desai, D.A., Antony, J. \& Patel, M.B. (2012). An assessment of the critical success factors for Six Sigma implementation in Indian industries. International Journal of Productivity and Performance Management, 61(4), 426-444. DOI: 10.1108/17410401211212670 
Fursule, N.V., Bansod, S.V. \& Fursule, S.N. (2012). Understanding the benefits and limitations of Six Sigma methodology. International Journal of Scientific and Research Publications, 2(1), 1-9.

Gamal Aboelmaged, M. (2011). Reconstructing Six Sigma barriers in manufacturing and service organizations: The effects of organizational parameters. International Journal of Quality \& Reliability Management, 28(5), 519-541.

Gosnik, D. \& Vujica-Herzog, N. (2010). Success factors for Six Sigma implementation in Slovenian manufacturing companies. Advances in Production Engineering \& Management, 5(4), 205-216.

Gowen Iii, C.R., Stock, G.N. \& McFadden, K. L. (2008). Simultaneous implementation of Six Sigma and knowledge management in hospitals. International Journal of Production Research, 46(23), 6781-6795. DOI: 10.1080/00207540802496162

Heuvel, J.V.D., Does, R.J.M.M. \& Vermaat, M.B.T. (2004). Six Sigma in a Dutch hospital: Does it work in the nursing department? Quality and Reliability Engineering International, 20, 419-426. DOI: 10.1002 /qre.656

Kundi, O.H.K. (2005). A study of Six sigma implementation and critical success factors. Pakistan's 9th International Convention on Quality Improvement, Karachi, Pakistan. 1-12.

Linderman, K., Schroeder, R.G., Zaheer, S. \& Choo, A.S. (2003). Six Sigma: A goal-theoretic perspective. Journal of Operations Management, 21, 193-203.

Montgomery, D.C. \& Woodall, W.H. (2008). An overview of Six Sigma. International Statistical Review, 76(3), 329-346. doi:10.1111/j.1751-5823.2008.00061.x

Sharma, S. \& Chetiya, A.R. (2012). An analysis of critical success factors for Six Sigma implementation. Asian Journal on Quality, 13(3), 294-308. DOI 10.1108/15982681211287810

Türkan, Y.S., Manisalı, E. \& Çelikkol, M.F. (2009). Evaluation of Critical Success Factors Effect on Six Sigma Project Success in Turkey's Manufacturing Sector. Journal of Engineering and Natural Sciences, Sigma, 27, 105-117.

Wang, F.K., Yeh, C.T. \& Chu, T.P. (2016). Using the design for Six Sigma approach with TRIZ for new product development. Computers \& Industrial Engineering, 98, 522-530. http://dx.doi.org/10.1016/j.cie.2016.06.014

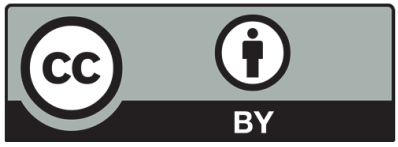

(C) 2017 by the authors; licensee Growing Science, Canada. This is an open access article distributed under the terms and conditions of the Creative Commons Attribution (CC-BY) license (http://creativecommons.org/licenses/by/4.0/). 